\title{
On the evolution of baboon greeting rituals
}

\section{Federica Dal Pesco1, 2, 3 \& Julia Fischer1, 2, 3}

\author{
1. Cognitive Ethology Laboratory, German Primate Center, Kellnerweg 4, 37077, \\ Goettingen, Germany \\ 2. Leibniz ScienceCampus Primate Cognition, Kellnerweg 4, 37077, Goettingen, Germany \\ 3. Department for Primate Cognition, Georg-August-University Goettingen, Kellnerweg 4, 37077, \\ Goettingen, Germany \\ ORCID ID Federica Dal Pesco: 0000-0003-2326-1185 \\ ORCID ID Julia Fischer: 0000-0002-5807-0074
}

Keywords: Rituals, Greeting behaviour, Papio spp., Cooperation, Spatial tolerance, male-male relationships

\begin{abstract}
To balance the trade-offs of male co-residence, males living in multi-male groups may exchange ritualized greetings. Although these non-aggressive signals are widespread in the animal kingdom, the repertoire described in the genus Papio is exceptional, involving potentially harmful behaviours such as genital fondling. Such greetings are among the most striking male baboon social interactions, yet their function remains disputed. Drawing on the comprehensive analysis from our own research on wild Guinea baboons, combined with a survey of the literature into other baboon species, we review the form and function of male-male ritualized greetings and their relation to the various social systems present in this genus. These ritualized signals differ between species in their occurrence, form, and function. While ritualized greetings are rare in species with the most intense contest competition, the complexity of and risk involved in greeting rituals increase with the degree of male-male tolerance and cooperation. The variety of societies found in this genus, combined with its role as a model for human socioecological evolution, sheds light on the evolution of ritualized behaviour in non-human primates and rituals in humans.
\end{abstract}

\section{Main Text}

\section{The function of rituals and ritualized behaviours}

Efficient communicative mechanisms aimed at maintaining group cohesion and regulating social relationships between group members are fundamental in balancing the trade-offs imposed by group co-residence [1]. Ritualized behaviours and communal rituals constitute one such mechanism and are thought to have played a crucial role in the evolution of complex societies [2]. Due to their stylized, attention-getting and often repetitive nature [3,4], ritualized behaviours are thought to be particularly effective in regulating social relationships as these features set them apart from other behaviours, greatly reducing their ambiguity [4,5]. In many animal societies, such "rule-governed" exchanges convey important social information [4]. A prime example are "ritualized greetings" that are central to signalling social status and buffering tension [6-9], assessing relationship quality and maintaining social bonds [1013], and promoting cooperation [11,14]. In human groups, such ritualized behaviours are often accompanied by symbolic value and sacred belief, thereby resulting in a more complex form of ritualized displays: rituals [2,15]. Thus, 
ritualized behaviours can be considered as a precursor of human rituals, where ritualized exchanges are additionally loaded with symbolic value $[2,15]$.

Human rituals are defined as causally opaque and preserved conventions that are culturally transmitted and involve synchronous and coordinated behavioural displays [16,17]. Collective rituals are powerful communicative mechanisms that have intense psychological and physiological effects on both participants and observers [18-20], resulting in a state of "psychological kinship" that fosters social assimilation and solidarity [17,21,22]. Extreme and intense rituals, specifically, can constitute costly and hard-to-fake signals that communicate honest commitment to in-group values $[23,24]$. Such rituals have strong effects on perceived trustworthiness, prosociality, and community longevity $[20,25,26]$. In addition to intensity and frequency [20,27], display efficacy depends on repetitions, complexity, degree of synchrony, and sacred value [16,22,28]. By increasing group cohesion [17,29], strengthening in-group affiliation

$[30,31]$, and promoting cooperation $[1,26,27]$, ritual practices are thought to play a crucial role in solving some of the adaptive challenges posed by group-living [1].

Rituals are considered universal trademarks of ancient and contemporary human societies [2,32] and are thought to have played a key role in making us human (c.f. [33]). During human evolution, these practices evolved from a rich repertoire of ritualized behaviours and likely became key in regulating relationships in larger communities characterized by an increased complexity of intra- and inter-group connections [33,34]. Indeed, in this complex social scenario, where frequent interactions between all community members became impractical and the risk of free-riders greater, the development of communal communicative mechanisms likely constituted an evolutionary advantage $[24,33]$. Paired with other evolutionary adaptations, such as bone tool production and artistic artefacts, the process of ritualization led to the emergence of "behavioural modernity" [35] and ultimately the evolution of contemporary human societies. As the extension of human cooperative networks beyond social units and kin classes is considered unique among primates [36-39], understanding how such social systems evolved is one of the crucial research question of evolutionary anthropology [40]. Furthermore, understanding the interplay of rituals, cooperation, and complexity is key to understanding human ultra-sociality and hyper-cooperation [17].

\section{The form and function of ritualized greetings in different baboon species}

Comparative approaches involving non-human primates are fundamental to the exploration and testing of hypotheses about early human evolution. Baboons (genus Papio), in particular, represent a powerful model for investigating ritualized behaviour as well as correlations with social systems, cooperation and tolerance in a non-human primate taxon [13]. Widely distributed over large parts of sub-Saharan Africa and the south-western part of the Arabian Peninsula, baboons are highly successful and well-studied African primates [41,42]. Because baboons were confronted with evolutionary challenges similar to those faced by early humans, they are considered an excellent model for human socioecological evolution [43,44]. Baboon evolutionary history paralleled that of hominins in the late Pliocene with the development of a drier climate and emergence of the African savannah [41,45]. In response to selective pressures, such as food resource fluctuation and increased predation risk, baboons evolved the ability to exploit a great variety of food types and developed large and complex social groups [41]. Similar to early humans, baboons are adapted to a wide variety of habitats, from semi-desert, savannah and rain forest, to high-altitude mountains [42,46,47]. In addition to ecological flexibility, baboons exhibit highly diverse social systems $[48,49]$ as well as ritualized greeting repertoires $[10,14]$. In this review, we introduce the socio-ecological diversity of this genus, their diverse social systems and varying 
levels of male cooperation, aggression and greeting behaviour between males, to help advance our understanding of the function of ritualized greetings and shed light on the evolution of human rituals.

Ritualized greetings are crucial communicative mechanisms between males [10] living in multi-male groups. These interactions are defined as short exchanges of non-aggressive signals between two individuals [50] and comprise a unior bi-directional exchange of cohesive or affiliative signals [51]. Notwithstanding the label "greetings", these exchanges are not limited to departures and encounters. Ritualized greetings are widespread in the animal kingdom, but the behavioural repertoire described in the genus Papio is exceptional (Figure 1). It involves highly stylized repetitive elements and potentially harmful behaviours such as genital fondling, which can jeopardize males' future reproductive success [10,14]. Greetings are one of the most striking male-male social interactions in baboons, and debates over their occurrence, context, and function in previous reports suggest substantial species-specific differences [13]. In the following, we will elucidate how these differences vary in relation to the social system of the species and, specifically the degree of male tolerance and cooperation (also see [52,53]). Such a comparative perspective is central to shed light on the evolutionary advantages that led to the widespread and complex system of rituals and cultures we see in humans.
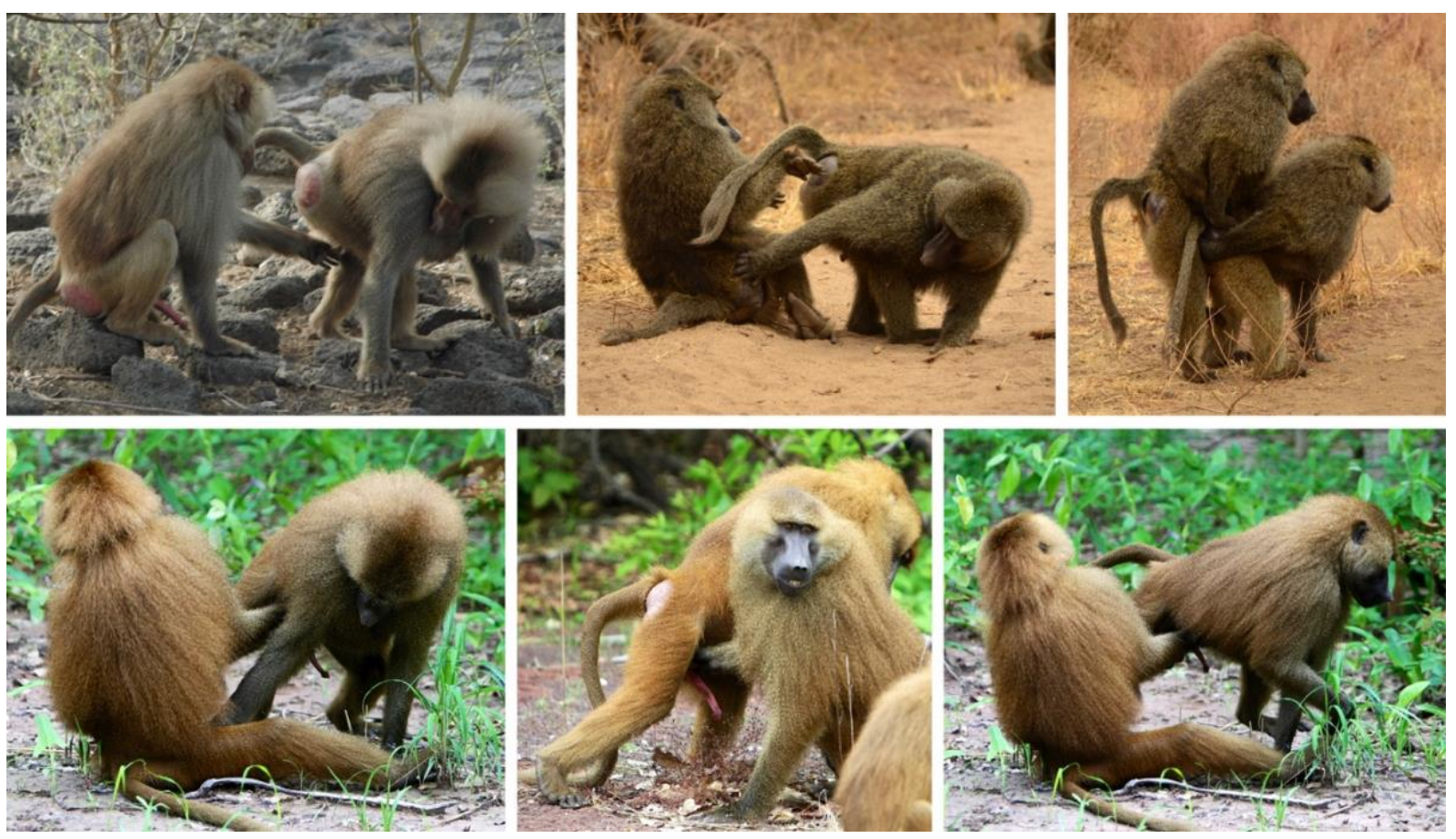

Figure 1. Examples of male-male ritualized greeting interactions in the genus Papio. Top/left: hamadryas baboons (photo: L. Swedell); top/right: olive baboons (photos: F. Paciência); bottom: Guinea baboons (photos: C. Girard-Buttoz).

According to the phylogenetic species concept [54], the genus Papio consists of six different species [42]: chacma (P. ursinus), olive (P. anubis), Kinda (P. kindae), and yellow (P. cynocephalus) baboons (also called COKY baboons - an acronym representing the first letter of each species - see [55]), on the one hand, and hamadryas (P. hamadryas) and Guinea (P. Papio) baboons, on the other. While the first four species live in stable multi-male multi-female groups characterized by female philopatry, the latter two species live in complex multilevel societies with predominant male philopatry and female-biased dispersal (reviewed in [55]). This major dichotomy results in very different types of 
primate societies that differ greatly in social organization, structure and mating system, culminating in very different male-male relationship dynamics.

In COKY baboons, related females share long-lasting bonds and compose the core of the group, while males disperse, sometimes multiple times, during their lives [41]. Males must thus repeatedly re-establish social relationships and dominance status throughout their lifespan. Male competition is intense as high-ranking males have priority of access over receptive females and sire the majority of offspring [56]. While males of all four species rarely spend time in close proximity or engage in social interactions, they do present different degrees of tolerance and cooperation [52,57]. In chacma baboons, affiliation and cooperation are virtually absent and males usually avoid each other [52,58,59]. In a direct comparison with Guinea baboons, adult male chacma baboon interactions were more likely to be agonistic [60]. Greeting-like behaviours mainly comprised quick walking-by accompanied by head bobbing, grunting or lip-smacking and sometimes quick touches ([60], R.M. Seyfarth \& J. Silk, personal communication, also see [61]) and appear to lack the intense and ritualized nature described in other Papio species [52]. Therefore, greeting-like behaviours among adult males are generally not a prominent feature in chacma baboons ([60]; also see [52]), and may even be completely absent in some populations [52]. The most prominent interactions between chacma males instead involve costly contest displays such as loud wahoo calls, chases, and running and jumping through trees [62,63]. These performances usually start during adolescence [64] when males start competing for status and reproductive access. Sometimes lasting over an hour, these energetically demanding displays are an indicator of male stamina and competitive ability, allow males to assess others' status and condition, and reduce the risk of costly physical fights [62]. Thus, in species that lack male-male tolerance and cooperation, displays requiring close spatial proximity between males are potentially too costly, preventing the emergence of frequent and intense greeting rituals involving affiliative gestures and risky contact behaviours.

Kinda baboons share a similar social organization as the other COKY baboons, but recent investigations indicate reduced direct and increased indirect male-male competition [65]. Female fertile phases seem to overlap, counteracting male monopolization strategies [65]. Male investment in social relationships with females is much higher than in other COKY species [66], suggesting that males provide important services to females. In turn, male services may affect female mate choice [65]. If male reproductive success is mostly driven by female preferences, males do not gain much from direct contests or coalitionary strategies. Accordingly, preliminary observations reported lower levels of malemale competition compared to other COKY baboon species [65] and the lack of both opportunistic coalitions and high levels of spatial tolerance between adult males (M. Petersdorf, personal communication). Due to the reduced need for male communicative mechanisms to balance the costs of competition and the benefits of cooperation, it would not be surprising if greetings were either absent or rare and rudimentary. In fact, while further corroboration is needed, male-male ritualized greetings were never reported in this species.

In contrast to the lack of male-male cooperation in chacma (and possibly in Kinda) baboons, male-male opportunistic coalitions are common in yellow and olive baboons. Such coalitions allow middle-ranking males to access receptive females by interfering with mate guarding by higher ranking males [67,68]. Similar to humans, these forms of cooperation emerged as a result of reduced individual competitive abilities, where partner choice in coalitions depends on the combined fighting potential of the partners relative to the opponent $[69,70]$. Males of both species engage in ritualized greeting behaviour, with some variation in occurrence and behavioural patterns [52]. In yellow baboons, greetings almost always involve a subordinate male approaching and presenting hind-quarters to a dominant male, who then either ignores the presentation or responds by mounting or manipulating the other male's genitals ([71] see 
also [51]). These exchanges are characterized by frequent and intense submissive elements and vocalizations and, occasionally, the expression of force by the dominant male through slapping and holding down the subordinate [71]. While detailed analyses on greeting function are still lacking, these patterns suggest that ritualized greetings are critical in signalling subordinate/dominant status and may represent an appeasement mechanism to avoid more hostile interactions [51,71].

Greetings are the most frequent interactions between male olive baboons and are characterized as friendly exchanges that are strikingly different from the generally highly competitive tendencies of males of this species. Almost all greetings occur in a neutral and non-competitive context and are often accompanied by affiliative signals such as lipsmacking and positive facial expressions [14]. Despite the positive nature of these exchanges, greetings in this species are also tentative and tense, with males frequently struggling to establish greeting roles or complete greeting attempts [14]. Physical contacts, mounting, and penis diddling are all quite rare, likely due to the fact that greetings are usually initiated by dominant males [14,72,73]. Greeting occurrence is lower in groups with stable dominance relationships, while higher rates can occur if within-group competition and tension is high [72]. The relationship "negotiation" typical of these exchanges seems to vary in relation to age and competitive tactics [14]. Based on a detailed analysis of the features and context of greetings, Smuts \& Watanabe [14] identified covariation between greeting patterns and male propensity to cooperate (also see $[73,74]$ ). Higher levels of cooperation were associated with less tense, less ambivalent, and fewer non-complete greetings. The authors concluded that, overall, greetings are crucial to establishing ruled-governed communicative exchanges between highly competitive males and play a role in cooperation [14].

Hamadryas and Guinea baboons, in contrast to COKY baboons, live in complex multilevel societies that may comprise several hundred individuals [55]. Both hamadryas and Guinea baboons are characterized by male philopatry $[75,76]$, while females disperse between different levels of the society. As a result, the strong ties between related and familiar males constitutes the core of these complex social systems [44,77-79]. Units composed of a leader/primary male, several associated females, and immatures constitute the innermost level of these societies [80,81]. Units can also include one or more follower/secondary males that may have occasional social but no sexual access to the unit females $[80,82]$. Several units form stable groupings, together with solitary/unaffiliated males, called clans or parties. These regularly aggregate into bands/gangs that share overlapping home ranges $[44,83]$. These elements set these societies apart from the other baboon species, resulting in very different male reproductive strategies and male-male relationship dynamics. The monandrous mating system and relatively small testis size $[44,84]$ in combination with the low level of male-male aggression and lack of agonistically-enforced rank [60,85], highlight the small degree of direct and indirect male competition in these two species.

There are also notable differences between hamadryas and Guinea baboons. In hamadryas baboons, pair bonds are maintained through male coercion [82,83]. Most interactions between individuals occur within the unit, whereas interunit interactions are rare and limited to between-leader threats and avoidance [82,83]. Leaders never affiliate with other leaders but may groom their unit followers [83,86], while solitary males may groom one another [87]. Occasionally, male-male alliances occur during inter-clan conflicts [87] and during communal unit defence by leader males and followers [48]. However, opportunistic coalitions against unit leaders have not been reported in the wild $([48,82,87]$ but see [88] for coalitions in a hamadryas, yellow, and hybrid baboons captive colony). Nevertheless, the groupings typical of these societies (i.e. clans or parties for Guinea baboons) were recently described as "extended and consolidated versions" of the male-male alliances in yellow and olive baboons (c.f. [55]). In striking contrast to COKY 
baboons, hamadryas males lack a rank order, often mutually back down from confrontations, and rarely display submissive signals ([85] p. 166-168). These patterns are attributed to the high potential costs of fighting for both winner and loser, including injuries and the risk of leaving females and offspring unguarded [59,85]. As a result, hamadryas baboon males evolved a general "respect of ownership", as shown in field experiments [89,90], and nonaggressive strategies to resolve conflicts [88].

Hamadryas baboon greetings are frequent, highly stereotyped, and characterized by a distinct gait, frequent hindquarter presentations, and a general tension between the participants $[82,87,88]$. These exchanges are brief and physical contact occurs only rarely $[82,87,91]$. While initial studies in the wild associated greetings with group departures from sleeping cliffs and were therefore termed "notification behaviour" [82], later investigations showed that most greetings occur within bands and in contexts of rivalry over the access to and control of females ([87] also see [92]). Field experiments and behavioural observations found that greetings are most likely to be initiated by males in possession of females and towards rivals [87,89]. Greeting likelihoods may also depend on the degree of establishment and attractivity of the female in possession as well as the level of motivation of the rival [87]. Studies on a captive population of hamadryas baboons, yellow baboons, and their hybrids confirmed these patterns and show that most greetings are associated with male status and occur in tense contexts such as aggressive episodes and competition over females, space, or food $[8,88,91,93]$. Studies on hybrid populations additionally show that greeting occurrence and symmetry are greater in hamadryas/hamadryas-like individuals compared to yellow/yellow-like individuals [93]. Interestingly, one captive study based on a stable hamadryas baboon group with a highly female-biased sex ratio, found that greetings can function as submission, peacekeeping, and alliance formation rather than appeasement in groups where male rivalry is reduced [94]. While greeting-like behaviours already occur during play between juvenile males [88], field studies highlight how fully ritualized greetings are largely confined to mature males [87]. The transition from bachelor to leader male results in a significant increase of ritualized and a decrease of affiliative exchanges between males [87]. These patterns are consistent with the role of greetings in this species as a negotiation mechanism to signal competitive power and diffuse tension between males by decreasing the probability of being challenged and/or avoiding fights that could end in failure (e.g. [87,93]).

Guinea baboon societies share several characteristics with hamadryas, but differ in two main aspects: the higher degree of tolerance and affiliation between males and the lack of male coercion toward females (reviewed in [44]). Males are often in close spatial proximity, establish affiliative relationships with preferred male partners whom they support in coalitions, and maintain very tolerant and relaxed relationships both within and between parties [44,78]. Compared to descriptions of other baboon species, Guinea baboon males show higher levels of spatial proximity and affiliation as well as lower rates of aggressive/submissive behaviour and rare injuries [60]. Similar to hamadryas baboons, males do not present a clear dominance hierarchy [13,60,78]. Rates of aggression towards females are less than half those in hamadryas baboons and repeated herding behaviour was not observed [80]. Females have high spatial freedom, play an active role in intersexual relationship maintenance, and can even respond to male aggression with counteraggression and female coalitions [80]. These patterns suggest Guinea baboon females exhibit a level of female choice [80], which in conjunction with male social philopatry (sensu [55]), likely resulted in the relaxed tenor of Guinea baboon relationships, the low level of competition, and the extreme rarity of male challenges and takeover attempts $([44,78,80]$ see also [95]).

In accordance with their tolerant social system, Guinea baboon greetings are more elaborate, intense and reciprocated compared to the ones described for all other baboon species [13]. In the wild, greetings are performed by males of all 
age classes, start to develop prior to maturity, and are the most common interactions between males [13,96]. Adult male greeting rates are higher in wild Guinea baboons (2.06/ hr; adapted from [13]) compared to wild yellow $(0.08 / \mathrm{hr}$; [71]), olive (1.20/hr; [14]) and hamadryas baboons (0.57/hr; [87]). Greetings occur independently of dyadic aggression, presence of oestrous females, close spatial proximity between males prior to the interaction, nor in temporal association with aggressive episodes, all of which emphasises that these interactions are not linked to tension or competition ([13], see [10] for similar results in a captive population). These exchanges are friendly and often accompanied by positive facial expressions and vocalizations, with almost all instances being complete, reciprocated, and involving physical contacts $[10,13]$. The lack of a dominance hierarchy or strong directionalities in greetings make them unlikely to be an expression of social status [10,13]. Instead, greetings occur independent of context and constitute brief "honest communicative exchanges" between males (c.f. [10]). In these large communities, greetings allow males to regulate social relationships at different social levels by signalling party membership and assessing relationship quality between spatially tolerant partners [13]. Intense greetings that include the "most risky and intimate form of contact" (c.f. [10]) are more likely between males with stronger affiliative relationships [13], suggesting they function to maintain and strengthen social bonds [10].

\section{On the evolution of ritualized greetings}

The variation in greetings between different baboon species (see table 1) provides a quasi-cross-sectional glimpse into the evolution of this complex signal. Communicative behaviours are assumed to evolve from simpler, functional behavioural patterns, such as touches and locomotion patterns. During the ritualization process, these patterns lose their original function and become increasingly stereotyped, stylized and elaborate, resulting in unambiguous and distinctive signals $[97,98]$. The gradient from greetings that mostly involve walking by in chacma, to incomplete and tentative greetings in yellow and olive baboons to the highly stylized notification and more elaborate greetings in hamadryas and Guinea baboons, respectively, may indeed represent different stages of elaboration in the evolution of greeting behaviours. Whether ritualized greetings evolve, and what their form and function are, seems to depend on the social system, the species-specific evolutionary pressures acting on males, and the resulting relationship dynamics [13].

As all baboon species for which data are reported present some greeting-like behaviours (see table 1), a rudimentary form of the behavioural patterns used during greetings is likely ancestral in this genus. This conclusion is in agreement with the occurrence of other affiliative ritualized behaviours in the tribe Papionini, such as triadic male-infant interactions and male-infants greeting, which also seem to be primitive in this tribe [99]. The occurrence and form of greetings in the genus Papio maps onto the deep split between the southern (i.e. chacma, Kinda and yellow baboons; see [100]) and the northern clade (i.e. olive, hamadryas and Guinea baboons; see [100]) and points to phylogenetic roots of the variation in ritualized greeting behaviour. Studies in a captive hybrid population also observed speciesspecific greeting patterns including a greater number of greeting elements displayed by hamadryas baboons and hamadryas-like hybrids compared to yellow baboons [101, also see 91]. In sum, a genetic component is either directly or indirectly involved in the variation in male greeting behaviour.

Greeting function varies between species, from signalling dominance status and buffering tension in species with low spatial tolerance between males, to testing relationship quality in more spatially tolerant ones (table 1). Frequent, elaborate and complex greeting rituals appear to be favoured in more cooperative and in spatially tolerant societies 
(table 1, also see $[12,13,52,53])$. This pattern is in agreement with the bond testing hypothesis, which states that risky interactions are ideally suited to testing the trust between social partners [102,103]. The most intense forms of greeting with direct genital manipulations are indeed extremely risky, as future male reproductive success is literally in the hands of a competitor [14]. The frequent, intense, and reciprocated greetings in the cooperative and tolerant Guinea baboons [13], where intense greetings are most likely between males with stronger affiliative relationships [13], are a prominent example, paralleling the link between greater levels of prosociality and intense and extreme rituals in humans $[20,25,26]$. Similar to humans, Guinea baboons live in large multilevel societies characterized by frequent encounters with familiar individuals of other parties or gangs and unfamiliar individuals from neighboring communities [13,44]. In this complex social scenario, these brief "honest communicative exchanges" (c.f. [10]) play a crucial role in signalling party membership [13], resembling the importance of human rituals in promoting group cohesion [17,29] and commitment to the group $[23,24]$.

Table 1. Occurrence and features of male-male ritualized greeting behaviour in the genus Papio

\begin{tabular}{|c|c|c|c|c|c|c|c|c|}
\hline \multirow{2}{*}{$\begin{array}{l}\text { Baboon } \\
\text { species }\end{array}$} & \multicolumn{8}{|c|}{ Ritualized greeting: occurrence and features } \\
\hline & $\begin{array}{l}\text { Occurre } \\
\text { nce }\end{array}$ & $\begin{array}{l}\text { Hourly } \\
\text { rate* }\end{array}$ & $\begin{array}{l}\text { Main male } \\
\text { initiator }\end{array}$ & $\begin{array}{l}\text { Physical } \\
\text { contact }\end{array}$ & $\begin{array}{l}\text { Intense } \\
\text { contact }\end{array}$ & $\begin{array}{l}\text { Complete/ } \\
\text { reciprocated }\end{array}$ & General tenor & Context/function \\
\hline Chacma & $\begin{array}{l}Y_{[60]} / \\
N_{[52]}\end{array}$ & $\begin{array}{l}0.088_{[60]} / \\
\mathrm{N}_{[52]}\end{array}$ & $\mathrm{N} / \mathrm{A}$ & $\mathrm{N} / \mathrm{A}$ & $\mathrm{N} / \mathrm{A}$ & $\mathrm{N} / \mathrm{A}$ & $\mathrm{N} / \mathrm{A}$ & $\mathrm{N} / \mathrm{A}$ \\
\hline Kinda & $\mathrm{N} / \mathrm{A}$ & $\mathrm{N} / \mathrm{A}$ & $\mathrm{N} / \mathrm{A}$ & $\mathrm{N} / \mathrm{A}$ & $\mathrm{N} / \mathrm{A}$ & $\mathrm{N} / \mathrm{A}$ & $\mathrm{N} / \mathrm{A}$ & $\mathrm{N} / \mathrm{A}$ \\
\hline Yellow & $Y_{[71]}$ & $0.08 / \mathrm{hr}[71]$ & $\begin{array}{l}\text { Subordinate } \\
71]\end{array}$ & $\mathrm{N} / \mathrm{A}$ & $\mathrm{N} / \mathrm{A}$ & $\mathrm{N} / \mathrm{A}$ & $\begin{array}{l}\text { Tense, } \\
\text { tentative[1]] }\end{array}$ & $\begin{array}{l}\text { Submissive/ } \\
\text { Signal status[71] }\end{array}$ \\
\hline Olive & $Y_{[14]}$ & $1.20 / \mathrm{hr}[14]$ & $\begin{array}{l}\text { Dominant }[14 \\
, 72,73]\end{array}$ & $\begin{array}{l}\text { Rare }[14,72,7 \\
\text { 3] }\end{array}$ & $\begin{array}{l}\text { Rare }[14,7 \\
2,73]\end{array}$ & $\begin{array}{l}55 \% \\
\text { completed }[14]\end{array}$ & $\begin{array}{l}\text { Tense, } \\
\text { tentative[14,72,73] }\end{array}$ & $\begin{array}{l}\text { Neutral/ } \\
\text { Negotiation[14] }\end{array}$ \\
\hline Hamadryas & $\mathrm{Y}[8,87]$ & $0.57 / \mathrm{hr}[87]$ & Leader[87-89] & $\begin{array}{l}\text { Rare }[82,87,9 \\
\text { 1] }\end{array}$ & $\begin{array}{l}\text { Rare[82,8 } \\
7,91]\end{array}$ & $\begin{array}{l}71.4 \% \\
\text { reciprocated[93] }\end{array}$ & Tense[82,87,88] & $\begin{array}{l}\text { Competitive/ } \\
\text { Tension } \\
\text { buffering[8,87,88,91-93] }\end{array}$ \\
\hline Guinea & $Y_{[10,13]}$ & $\begin{array}{l}2.06 / \mathrm{hr}[13] \\
* *\end{array}$ & $\begin{array}{l}\text { No rank } \\
\text { effect[10] }\end{array}$ & $93.4 \%[13]$ & $\begin{array}{l}59.2 \%[1 \\
3]\end{array}$ & $\begin{array}{l}99.7 \% \\
\text { completed }[13] \\
81.9 \% \\
\text { reciprocated }[13]\end{array}$ & $\begin{array}{l}\text { Positive, } \\
\text { relaxed }[10,13]\end{array}$ & $\begin{array}{l}\text { Neutral }[10,13] / \\
\text { Signal party } \\
\text { membership[13], assess } \\
\text { relationship quality[10,13] }\end{array}$ \\
\hline
\end{tabular}

$\mathrm{Y}=$ yes; $\mathrm{N}=$ no; $\mathrm{N} / \mathrm{A}=$ information not available; * rates refer to adult male greetings; $* *$ Rates recalculated for adults from original values published in [13].

In other primate taxa, such as macaques [12,53], the occurrence of ritualized behaviours also seems to be associated with male tolerance and cooperation. Intolerant male rhesus (Macaca mulatta) and Japanese macaques (Macaca fuscata) lack ritualized affiliative contacts, while ritualized greetings and/or triadic male-infant interactions are present in species with male tolerance and coalitions such as bonnet (Macaca radiata: [104]), Assamese (Macaca assamensis: [105]) and Barbary (Macaca sylvanus: [106]) macaques (discussed in [53], also see [99]). Similarly, in the genus Pan, intense genogenital rubbing between females [7] are described for bonobos (Pan paniscus), which are known for their low aggression and greater level of tolerance [107]. 
Although further systematic comparative studies will be crucial to understanding if these patterns hold across the Primate order, the negative link between more competitive/hierarchical male societies and the occurrence of affiliative ritualized behaviours does not seem to be limited to the genus Papio. What is still unclear, is whether ritualized interactions and tolerance/cooperation emerged in response to similar evolutionary forces, or one feature promoted the emergence of the other [13]. Nonetheless, our analyses of baboon "ritual ceremonies" (c.f. [14]) reinforce the assumption that intense ritualized behaviour and rituals developed in parallel with tolerance and cooperation in nonhuman primates and humans. Thus, our findings support human evolutionary theories suggesting that the emergence of fully symbolic behaviour, often attributed to demographic changes in population densities [108], might have been facilitated by a transition from more aggressive to more tolerant and cooperative social styles during the middle/late Pleistocene [109].

\section{Acknowledgments}

We are grateful to Larissa Swedell, Filipa Paciência, and Cédric Girard-Buttoz for providing photos depicting greeting behaviour in different Papio species. We would like to thank Robert Seyfarth, Joan Silk, and Urs Kalbitzer for helpful discussions about greeting behaviour in chacma baboons. This research was supported by the Deutsche Forschungsgemeinschaft (DFG, German Research Foundation) - Project number 254142454/GRK 2070.

\section{Authors' Contributions \\ F.D.P. and J.F. wrote the paper.}

\section{Competing Interests}

We have no competing interests.

\section{References}

1. Watson-Jones RE, Legare CH. 2016 The Social Functions of Group Rituals. Curr. Dir. Psychol. Sci. 25, 4246. (doi:10.1177/0963721415618486)

2. Rossano MJ. 2015 The Evolutionary Emergence of Costly Rituals. PaleoAnthropology , 78-100. (doi:10.4207/PA.2015.ART97)

3. Rappaport RA. 1979 The obvious aspects of ritual. In Ecology, Meaning, and Religion, pp. 173-219. Berkeley: North Atlantic Books.

4. Rossano M.J. 2012 The essential role of ritual in the transmission and reinforcement of social norms. Psychol. Bull. 138, 529-549. (doi:10.1037/a0027038)

5. Cullen J.M. 1966 E. Ritualization of animal activities in relation to phylogeny, speciation and ecology: Reduction of ambiguity through ritualization. Philos. Trans. R. Soc. London B 251, 363-374. (doi:10.1136/bmj.4.5577.438-a)

6. East M.L., Hofer H., Wickler W. 1993 The erect 'penis' is a flag of submission in a female-dominated society: greetings in Serengeti spotted hyenas. Behav. Ecol. Sociobiol. 33, 355-370. (doi:10.1007/BF00170251)

7. Hohmann G., Fruth B. 2000 Use and function of genital contacts among female bonobos. Anim. Behav. 60, 
107-120. (doi:10.1006/anbe.2000.1451)

8. Colmenares F., Hofer H., East M.L. 2000 Greeting Ceremonies in Baboons and Hyenas. In Natural Conflict Resolution (eds F Aureli, FBM de Waal), pp. 94-96. Berkeley: University of California Press.

9. Aureli F., Schaffner C.M. 2007 Aggression and conflict management at fusion in spider monkeys. Biol. Lett. 3, 147-149. (doi:10.1098/rsbl.2007.0041)

10. Whitham J.C., Maestripieri D. 2003 Primate Rituals: The Function of Greetings between Male Guinea Baboons. Ethology 109, 847-859. (doi:10.1046/j.0179-1613.2003.00922.x)

11. Smith J.E., Powning K.S., Dawes S.E., Estrada J.R., Hopper A.L., Piotrowski S.L., Holekamp K.E. 2011 Greetings promote cooperation and reinforce social bonds among spotted hyaenas. Anim. Behav. 81, 401415. (doi:10.1016/j.anbehav.2010.11.007)

12. De Marco A., Sanna A., Cozzolino R., Thierry B. 2014 The function of greetings in male Tonkean macaques. Am. J. Primatol. 76, 989-998. (doi:10.1002/ajp.22288)

13. Dal Pesco F., Fischer J. 2018 Greetings in male Guinea baboons and the function of rituals in complex social groups. J. Hum. Evol. 125, 87-98. (doi:10.1016/j.jhevol.2018.10.007)

14. Smuts B., Watanabe J.M. 1990 Social relationships and ritualized greetings in adult male baboons (Papio cynocephalus anubis). Int. J. Primatol. 11, 147-172. (doi:10.1007/BF02192786)

15. Bell C.M. 1997 Ritual: Perspectives and Dimensions. New York: Oxford University Press. (doi:10.2307/1387617)

16. Legare C.H, Souza A.L. 2012 Evaluating ritual efficacy: Evidence from the supernatural. Cognition 124, 1-15. (doi:10.1016/j.cognition.2012.03.004)

17. Whitehouse H., Lanman J.A. 2014 The Ties That Bind Us: Ritual, fusion, and identification. Curr. Anthropol. 55, 674-695. (doi:10.1086/678698)

18. Konvalinka I., Xygalatas D., Bulbulia J., Schjødt U., Jegindø E., Wallot S. 2011 Synchronized arousal between performers and related spectators in a fire-walking ritual. Pnas 108, 8514-8519. (doi:10.1073/pnas.1016955108)

19. Xygalatas D., Konvalinka I., Bulbulia J.A., Roepstorff A. 2011 Quantifying Collective Effervescence: HeartRate Dynamics at a Fire-Walking Ritual. Commun. Integr. Biol. 4, 735-738. (doi:10.4161/cib.17609)

20. Xygalatas D., Mitkidis P., Fischer R., Reddish P., Skewes J., Geertz A.W., Roepstorff A., Bulbulia J. 2013 Extreme Rituals Promote Prosociality. Psychol. Sci. 24, 1602-1605. (doi:10.1177/0956797612472910)

21. Whitehouse H. 2004 Modes of religiosity: A cognitive theory of religious transmission. Lanham: AltaMira Press.

22. Fischer R., Callander R., Reddish P., Bulbulia J. 2013 How Do Rituals Affect Cooperation?: An Experimental Field Study Comparing Nine Ritual Types. Hum. Nat. 24, 115-125. (doi:10.1007/s12110-0139167-y)

23. Sosis R, Alcorta C. 2003 Signaling, Solidarity, and the Sacred: The Evolution of Religious Behavior. Evol. Anthropol. 12, 264-274. (doi:10.1002/evan.10120)

24. Henrich J. 2009 The evolution of costly displays, cooperation and religion. credibility enhancing displays and their implications for cultural evolution. Evol. Hum. Behav. 30, 244-260.

(doi:10.1016/j.evolhumbehav.2009.03.005)

25. Sosis R., Bressler E.R. 2003 Signaling Theory of Religion. CrossCultural Res. 37, 211-239. (doi:10.1177/1069397103251426)

26. Soler M. 2012 Costly signaling, ritual and cooperation: Evidence from Candomblé, an Afro-Brazilian religion. Evol. Hum. Behav. 33, 346-356. (doi:10.1016/j.evolhumbehav.2011.11.004)

27. Sosis R., Ruffle B.J. 2003 Religious Ritual and Cooperation: Testing for a Relationship on Israeli Religious and Secular Kibbutzim. Curr. Anthropol. 44, 713-722. (doi:10.1086/379260)

28. Hagen E.H., Bryant G.A. 2003 Music and dance as a coalition signaling system. Hum. Nat. 14, $21-51$. (doi:10.1007/s12110-003-1015-z)

29. Durkheim E. 2001 The elementary forms of religious life. London: Oxford University Press.

30. Legare C.H., Watson-Jones R.E. 2015 The evolution and ontogeny of ritual. Handb. Evol. Psychol. , 829-847. (doi:10.1002/9781119125563.evpsych234)

31. Wen N.J., Herrmann P.A., Legare C.H. 2016 Ritual increases children's affiliation with in-group members. 
Evol. Hum. Behav. 37, 54-60. (doi:10.1016/j.evolhumbehav.2015.08.002)

32. Whitehouse H. 2012 Ritual, Cognition, and Evolution. In Grounding the Social Sciences in the Cognitive Sciences (ed R Sun), London: MIT Press.

33. Rossano M.J. 2016 The Ritual Origins of Humanity. In Interdisziplinäre Anthropologie (ed HM (eds) IA Hartung G.), Wiesbaden: Springer VS. (doi:10.1007/978-3-658-10978-3_1)

34. Rossano M.J. 2009 Ritual Behaviour and the Origins of Modern Cognition. Cambridge Archaeol. J. 19, 243256. (doi:10.1017/S09597743090000)

35. Mcbrearty S., Brooks A.S. 2000 The revolution that wasn't: A new interpretation of the origin of modern human behavior. J. Hum. Evol. 39, 453-563. (doi:10.1006/jhev.2000.0435)

36. Henrich J., Henrich N. 2006 Culture, evolution and the puzzle of human cooperation. Cogn. Syst. Res. 7, 220-245. (doi:10.1016/j.cogsys.2005.11.010)

37. Boyd R., Richerson P.J. 2009 Culture and the evolution of human cooperation. Philos. Trans. R. Soc. B Biol. Sci. 364, 3281-3288. (doi:10.1098/rstb.2009.0134)

38. Rand D.G., Nowak M.A. 2013 Human cooperation. Trends Cogn. Sci. 17, 413-425. (doi:10.1016/j.tics.2013.06.003)

39. Apicella C.L., Silk J.B. 2019 The evolution of human cooperation. Curr. Biol. 29, R447-R450. (doi:10.1016/j.cub.2019.03.036)

40. Alvard M. 2012 Human sociality. In The Evolution of Primate Societies (ed PK et al. J. Mitani, J. Call), London Chicago: University of Chicago Press.

41. Barrett L., Henzi S.P. 2008 Baboons. Curr. Biol. 18, R404-406. (doi:10.1016/j.cub.2008.02.074)

42. Zinner D., Wertheimer J., Liedigk R., Groeneveld L.F., Roos C. 2013 Baboon phylogeny as inferred from complete mitochondrial genomes. Am. J. Phys. Anthropol. 150, 133-140. (doi:10.1002/ajpa.22185)

43. Swedell L., Plummer T. 2019 Social Evolution in Plio-Pleistocene Hominins: Insights from Hamadryas Baboons and Paleoecology. J. Hum. Evol., 137, 102667. (doi: 10.1016/j.jhevol.2019.102667)

44. Fischer J., Kopp G.H., Dal Pesco F., Goffe A., Hammerschmidt K., Kalbitzer U., Klapproth M., Maciej P., Ibrahima N., Patzelt A., Zinner D. 2017 Charting the neglected West: The social system of Guinea baboons. Am. J. Phys. Anthropol. 162, 15-31. (doi:10.1002/ajpa.23144)

45. Jolly C.J. 2001 A Proper study for Mankind: Analogies from the Papioin Monkeys and Their Implications for Human Evolution. Am. J. Phys. Anthropol. 117, 169-181. (doi:10.1002/ajpa.10021)

46. Henzi S.P., Barrett L. 2005 The historical socioecology of savanna baboons (Papio hamadryas). J. Zool. 265, 215-226. (doi:10.1017/S0952836904006399)

47. Kingdon J. 1997 The Kingdon Field Guide to African Mammals. London: Academic Press.

48. Swedell L. 2011 African Papionins: Diversity of Social Organisation and Ecological Flexibility. In Primates in Perspective, pp. 241-277. London: Oxford University Press.

49. Fischer J., Higham J.P., Alberts S.C., Barrett L., Beehner J.C., Bergman T.J., Carter A.J., Collins A., Elton S., Fagot J., da Silva M.J.F., Hammerschmidt K., Henzi P., Jolly C.J., Knauf S., Kopp G.H., Rogers J., Roos C., Roos C., Seyfarth R.M., Silk J., Snyder-Mackler N., Staedele V., Swedell L., Wilson M.J., Zinner D. 2019 The Natural History of Model Organisms: Insights into the evolution of social systems and species from baboon studies. Elife, 8, e50989. (doi:10.7554/eLife.50989)

50. Kutsukake N., Suetsugu N., Hasegawa T. 2006 Pattern, distribution, and function of greeting behavior among black-and-white colobus. Int. J. Primatol. 27, 1271-1291. (doi:10.1007/s10764-006-9072-x)

51. Peláez F. 1982 Greeting movements among adult males in a colony of baboons:Papio hamadryas, P. cynocephalus and their hybrids. Primates 23, 233-244. (doi:10.1007/BF02381163)

52. Henzi S.P., Clarke P., Barrett L., Noë R., Jolly C.J. 2008 The genetics and biogeography of coalition formation in savanna baboons. INCORE Rep. (doi:https://pdfs.semanticscholar.org/db44/4f3dd0b5fb1d4baeb0c8a5391a94e17ecb05.pdf)

53. De Marco A. 2017 Male Greetings. In The International Encyclopedia of Primatology, Hoboken, NJ, USA: John Wiley \& Sons, Inc. (doi:10.1002/9781119179313.wbprim0007)

54. Cracraft J. 1989 Species as entities of biological theory. In Speciation and its Consequences (eds D Otte, JA 
Endler), pp. 28-59. Sunderland, MA: MS: Sinauer.

55. Jolly C.J. In press. Philopatry at the Frontier: a demographically-driven scenario for the evolution of multilevel societies in baboons (Papio). J. Hum. Evol.

56. Gesquiere L.R., Learn N.H., Simao M.C.M., Onyango P.O., Alberts S.C., Altmann J. 2011 Life at the top: rank and stress in wild male baboons. Science 333, 357-60. (doi:10.1126/science.1207120)

57. Jolly C.J. 2007 Baboons, mandrills, and mangabeys: Afro-papionin socioecology in a phylogenetic perspective. In Primates in Perspective (ed CJ Campbell), pp. 240-251. Oxford University Press.

58. Henzi S.P., Weingrill T., Barrett L. 1999 Male behaviour and the evolutionary ecology of chacma baboons. S. Afr. J. Sci. , 240-242.

59. Henzi P., Barrett L. 2003 Evolutionary Ecology, Sexual Conflict, and Behavioral Differentiation Among Baboon Populations. Evol. Anthropol. 12, 217-230. (doi:10.1002/evan.10121)

60. Kalbitzer U., Heistermann M., Cheney D., Seyfarth R., Fischer J. 2015 Social behavior and patterns of testosterone and glucocorticoid levels differ between male chacma and Guinea baboons. Horm. Behav. 75, 100-110. (doi:10.1016/j.yhbeh.2015.08.013)

61. Saayman G.S. 1971 Behaviour of the adult males in a troop of free-ranging chacma baboons (papio ursinus). Folia Primatol. 15, 36-57. (doi:10.1159/000155366)

62. Kitchen D.M., Seyfarth R.M., Fischer J., Cheney D.L. 2003 Loud calls as indicators of dominance in male baboons (Papio cynocephalus ursinus). Behav. Ecol. Sociobiol. 53, 374-384. (doi:10.1007/s00265-003-0588-1)

63. Fischer J., Kitchen D.M., Seyfarth R.M., Cheney D.L. 2004 Baboon loud calls advertise male quality: Acoustic features and their relation to rank, age, and exhaustion. Behav. Ecol. Sociobiol. 56, 140-148. (doi:10.1007/s00265-003-0739-4)

64. Fischer J., Hammerschmidt K., Cheney D.L., Seyfarth R.M. 2002 Acoustic features of male baboon loud calls: Influences of context, age, and individuality. J. Acoust. Soc. Am. 111, 1465-1474.

(doi:10.1121/1.1433807)

65. Petersdorf M., Weyher A.H., Kamilar J.M., Dubuc C., Higham J.P. 2019 Sexual selection in the Kinda baboon. J. Hum. Evol. 135, 1-12. (doi:10.1016/j.jhevol.2019.06.006)

66. Weyher A., Phillips-conroy J.E., Fourrier M.S., Jolly C.J. 2014 Male-Driven Grooming Bouts in Mixed-Sex Dyads of Kinda Baboons (Papio kindae). Folia Primatol. 85, 178-191. (doi:10.1159/000362544)

67. Bercovitch F.B. 1988 Coalitions, cooperation and reproductive tactics among adult male baboons. Anim. Behav. 36, 1198-1209. (doi:10.1016/S0003-3472(88)80079-4)

68. Noë R., Sluijter A.A. 1990 Reproductive tactics of male savanna baboons. Behaviour 113, 117-69. (doi:10.1163/156853990X00455)

69. Noë R. 1986 Lasting alliances among adult male savannah baboons. In Primate Ontogeny, Cognition and Social Behaviour (eds JG Else, PC Lee), pp. 381-392. Cambridge: Cambridge University Press.

70. Benenson J.F., Markowitz H., Emery Thompson M., Wrangham R.W. 2009 Strength determines coalitional strategies in humans. Proc. R. Soc. B Biol. Sci. 276, 2589-2595. (doi:10.1098/rspb.2009.0314)

71. Hausfater G., Takacs D. 1987 Structure and Function of Hindquarter Presentations in Yellow Baboons (Papio cynocephalus). Ethology 74, 297-319. (doi:10.1111/j.1439-0310.1987.tb00941.x)

72. Hall K.R.L., DeVore I. 1965 Baboon social behavior. In Primate Behavior: Field Studies of Monkeys and Apes (ed Irven DeVore), pp. 53-110. New York: Holt, Rinehart and Winston.

73. DeVore I. 1962 Social behavior and organization of baboon troops. University of Chicago.

74. Ransom T.W. 1981 Beach troop of the Gombe. Lewisburg: Bucknell University Press.

75. Kopp G.H., Fischer J., Patzelt A., Roos C., Zinner D. 2015 Population genetic insights into the social organization of Guinea baboons (Papio papio): Evidence for female-biased dispersal. Am. J. Primatol. 77, 878889. (doi:10.1002/ajp.22415)

76. Städele V., Van Doren V., Pines M., Swedell L., Vigilant L. 2015 Fine-scale genetic assessment of sexspecific dispersal patterns in a multilevel primate society. J. Hum. Evol. 78, 103-113. (doi:10.1016/j.jhevol.2014.10.019)

77. Colmenares F. 1992 Clans and harems in a colony of hamadryas and hybrid baboons: male kinship, 
familiarity and the formation of brother-teams. Behaviour 121, 61-93. (doi:10.1163/156853992X00444)

78. Patzelt A., Kopp G.H., Ndao I., Kalbitzer U., Zinner D., Fischer J. 2014 Male tolerance and male-male bonds in a multilevel primate society. Proc. Natl. Acad. Sci. U. S. A. 111, 14740-14745. (doi:10.1073/pnas.1405811111)

79. Städele V., Pines M., Swedell L., Vigilant L. 2016 The ties that bind: Maternal kin bias in a multilevel primate society despite natal dispersal by both sexes. Am. J. Primatol. 78, 731-744. (doi:10.1002/ajp.22537)

80. Goffe A.S., Zinner D., Fischer J. 2016 Sex and friendship in a multilevel society: behavioural patterns and associations between female and male Guinea baboons. Behav. Ecol. Sociobiol. 70, 323-336. (doi:10.1007/s00265-015-2050-6)

81. Swedell L. 2006 Strategies of Sex and Survival in Hamadryas Baboons: Through a Female Lens. Upper Saddle River, NJ: Pearson Prentice Hall.

82. Kummer H. 1968 Social organization of hamadryas baboons. Basel: S. Karger.

83. Schreier A.L., Swedell L. 2009 The fourth level of social structure in a multi-level society: Ecological and social functions of clans in Hamadryas Baboons. Am. J. Primatol. 71, 948-955. (doi:10.1002/ajp.20736)

84. Jolly C.J., Phillips-Conroy J.E. 2006 Testicular size, developmental trajectories, and male life history strategies in four baboon taxa. In Reproduction and fitness in baboons: behavioral, ecological, and life history perspectives (eds L Swedell, SR Leigh), pp. 257-275. New York: Springer.

85. Kummer H. 1997 In quest of the sacred baboon : a scientist's journey. Princeton, New Jersey: Princeton University Press.

86. Chowdhury S., Pines M., Saunders J., Swedell L. 2015 The adaptive value of secondary males in the polygynous multi-level society of hamadryas baboons. Am. J. Phys. Anthropol. 158, 501-513. (doi:10.1002/ajpa.22804)

87. Abegglen J-J. 1984 On socialization in hamadryas baboons: a field study. London: Bucknell University Press.

88. Colmenares F. 1991 Greeting behaviour between male baboons: oestrous females, rivalry and negotiation. Anim. Behav. 41, 49-60. (doi:10.1016/S0003-3472(05)80502-0)

89. Kummer H., Götz W., Angst W. 1974 Triadic Differentiation: An Inhibitory Process Protecting Pair Bonds in Baboons. Behaviour 49, 62-87. (doi:10.1017/CBO9781107415324.004)

90. Bachmann C., Kummer H. 1980 Male Assessment of Female Choice in Hamadryas Baboons. Behav. Ecol. Sociobiol. 6, 315-321. (doi:10.1007/BF00292774)

91. Colmenares F. 1990 Greeting Behaviour in Male Baboons, I: Communication, Reciprocity and Symmetry. Behaviour 113, 81-115. (doi:10.1163/156853990X00446)

92. Kummer H., Banaja A.A., Abokhatwa A.N., Ghandour A.M. 1985 Differences in Social-Behavior between Ethiopian and Arabian Hamadryas Baboons. Folia Primatol. 45, 1-8. (doi:10.1159/000156187)

93. Colmenares F. 1991 Greeting, aggression, and coalitions between male baboons: Demographic correlates. Primates 32, 453-463. (doi:10.1007/BF02381936)

94. Fraser Ó., Plowman A.B. 2007 Function of notification in Papio hamadryas. Int. J. Primatol., 28, 1439-1448. (doi: 10.1007/s10764-007-9185-x)

95. Jolly C.J. 2009 Fifty Years of Looking at Human Evolution: Backward, Forward, and Sideways. Curr. Anthropol. 50, 187-199. (doi:https://doi.org/10.1086/597196)

96. Dal Pesco F. 2013 Greeting behaviour in wild Guinea baboons (Papio papio) in the Niokolo-Koba National Park, Senegal. Freie Univerität zu Berlin, Germany.

97. Zahavi A. 1980 Ritualization and the Evolution of Movement Signals. Behaviour 72, 77-81. (doi:10.1163/156853980x00050)

98. Huxley J.S. 1914 The Courtship-habits of the Great Crested Grrebe (Podiceps cristatus); with an addition to the Theory of Sexual Selection. Proc. Zool. Soc. London 84, 491-562. (doi:10.1111/j.1469-

7998.1914.tb07052.x)

99. Maestripieri D. 1998 The evolution of male-infant interactions in the tribe Papionini (Primates:

Cercopithecidae). Folia Primatol., 69, 247-251. (doi:10.1159/000021633)

100. Rogers J., Raveendran M., Harris R.A., Mailund T., Leppälä K., Athanasiadis G., Schierup M.H., Cheng J., 
Munch K., Walker J.A. and Konkel M.K., Jordan M., Steely C.J., Beckstrom T.O., Bergey C., Burrell A., Schrempf D., Noll A., Kothe M., Kopp G.H., Liu Y., Murali S., Billis K., Martin F.J., Muffato M., Cox L., Else J., Disotell T., Muzny D.M., Phillips-Conroy J., Aken B., Eichler E.E., Marques-Bonet T., Kosiol C, Batzer M.A., Hahn M.W., Tung J., Zinner D., Roos C., Jolly C.J., Gibbs R.A., Worley K.C., Baboon Genome Analysis Consortium 2019. The comparative genomics and complex population history of Papio baboons. Science advances, 5, p.eaau6947. (doi: 10.1126/sciadv.aau6947)

101. Peláez F. 1982 Greeting movements among adult males in a colony of baboons: Papio hamadryas, $P$. cynocephalus and their hybrids. Primates, 23, 233-244. (doi: 10.1007/BF02381163)

102. Zahavi A. 1977 The testing of a bond. Anim. Behav., 25, 246-247. (doi:https://doi.org/10.1016/00033472(77)90089-6)

103. Zahavi A., Zahavi A. 1997 The Handicap Principle: A Missing Piece of Darwin's Puzzle. Oxford: Oxford Univ. Press.

104. Silk J.B. 1994 Social relationships of male bonnet macaques: male bonding in a matrilineal society. Behaviour 130, 271-291. (doi:10.1017/CBO9781107415324.004)

105. Kalbitz J., Schülke O., Ostner J. 2017 Triadic male-infant-male interaction serves in bond maintenance in male Assamese macaques. PLoS One 12,16-19. (doi:10.1371/journal.pone.0183981)

106. Kubenova B., Konecna M., Majolo B., Smilauer P., Ostner J., Schülke O. 2017 Triadic awareness predicts partner choice in male-infant-male interactions in Barbary macaques. Anim. Cogn. 20, 221-232. (doi:10.1007/s10071-016-1041-y)

107. Hare B., Wobber V., Wrangham R.W. 2012 The self-domestication hypothesis: Evolution of bonobo psychology is due to selection against aggression. Anim. Behav. 83, 573-585. (doi:10.1016/j.anbehav.2011.12.007)

108. Powell A., Shennan S., Thomas M.G. 2009 Late Pleistocene demography and the appearance of modern human behavior. Science (80-. ). 324, 1298-1301. (doi:10.1126/science.1170165)

109. Cieri R.L., Churchill S.E., Franciscus R.G., Tan J., Hare B. 2014 Craniofacial Feminization, Social Tolerance, and the Origins of Behavioral Modernity. Curr. Anthropol. 55, 419-443. (doi:10.1086/677209) 